\title{
Digital literacy: The quest of an inclusive definition
}

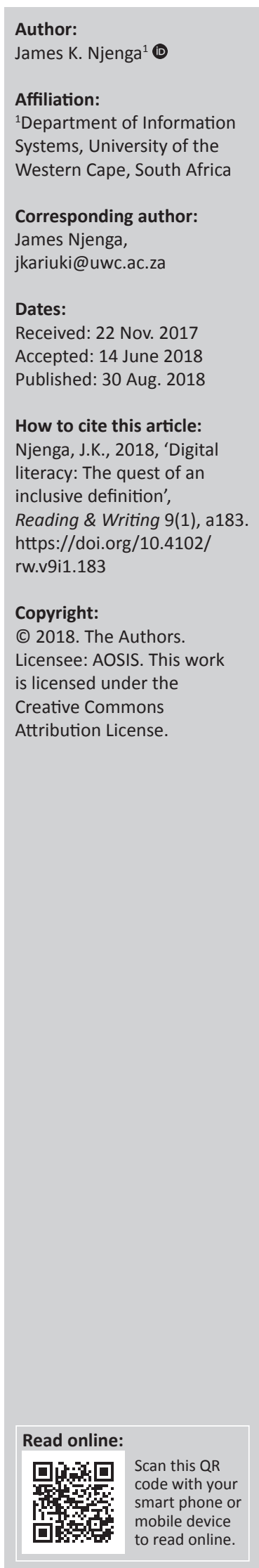

Forces of globalisation and economic competition enhanced by, among others, the digital technologies, are radically transforming the social context. Digital technologies are characterised by a powerful and pervasive Internet as well as the related information and communication technologies. Globalisation is facilitated by the universally accessible, reliable and inexpensive communication assisted by these digital technologies. However, there is growing and valid scepticism regarding the digitally influenced socio-economic emancipation. This scepticism is mainly driven by a lack of understanding of digital literacy as a holistic process of creating the necessary social, economic and political changes within a given context. The understanding of digital literacy therefore needs to join a number of seemingly divergent views of digital technology when dealing with these technologies' benefits in socio-economic emancipation. This understanding of digital literacy should therefore be shaped and focused more on understanding how digital literacy impacts the poor and marginalised, especially in looking at the socio-economic welfare of these marginalised sections of the society. This article discusses digital literacy by firstly looking at the shortcomings of the available definitions and approaches and then recommends a socio-economic development-orientated definition. The article brings to the fore the most critical digital literacy issues for socio-economic development. These issues are important; they ensure that digital literacy is not viewed in isolation, but rather in terms of its outcomes and consequences, especially with regard to socio-economic development.

\section{Introduction}

Digital technologies are major drivers of globalisation and related economic competitiveness, which in turn, have become powerful forces in the social context (Avgerou 2010; Czerniewicz, Ravjee \& Mlitwa 2006; Garrido et al. 2012). This makes digital literacy (DL) essential for progress in the contemporary era (Pangrazio 2016). Digital technology-based competitiveness has been studied in business for a long time (Roztocki \& Weistroffer 2016). However, little has been done on societal competitiveness. To the general masses, the ubiquity of digital technologies has been credited not only for the accelerated rate of globalisation and economic competition, but also for their social impacts and controversies, at both the individual and societal levels (Baase 2012). The digital technologies view of economic competition and competitiveness requires individuals to have DL, which is synonymous with the ability of individuals to participate in the economy through skills and creativity enabled by the digital technologies (Klecun 2008). Globalisation involves the reorganisation of social and economic relations, interdependences and interconnectedness (Avgerou 2010). As a corollary to this, globalisation would need digital technologies that facilitate universally ${ }^{1}$ accessible, reliable and inexpensive communication. Not with standing the potential benefits of globalisation and economic competitiveness, there are concerns on the use of digital technologies related to, among others, 'antisocial, anticommunity effects', threats to security and privacy, challenges to intellectual property as well as the exacerbation of the existing inequalities between the haves and have-nots' (Baase 2012:5).

Furthermore, there is growing and valid scepticism on the digitally influenced socio-economic liberation. Three main observations that drive this scepticism are identified from the existing research. Firstly, there is a lack of commensurate socio-economic development arising from the use of digital technologies among the poor and marginalised communities (Cibangu, Hepworth \& Champion 2017; Watkins 2011). Socio-economic developments among the poor and the marginalised still remain largely incomparable with the developments among the affluent members of the society, even when the poor are perceived to be using digital technologies (Alam \& Imran 2015; Haugh \& Talwar 2016; Klecun 2008). Secondly, the macro-level nature of empirical studies on the outcomes of digital technology use is more often than not focused on economic for many to own or access these devices. Of course, in Africa this remains to be a challenge and a major point requiring ongoing research. 
improvements, and not the whole socio-economic development and well-being at the micro-level, with direct impact on the individuals and societies (Cibangu et al. 2017; El-Darwiche et al. 2012; Roztocki \& Weistroffer 2016). While the macro-level focus (often on gross domestic product [GDP], the labour market and international esteem) is welcomed, it may have the proclivity to leave out the other critical factors that are essential for socio-economic development. Such factors include a population's education, political stability and social liberties, the standard of living and general health (Harris 2016; Roztocki \& Weistroffer 2016). Harris (2016) attributes this to either a lack of genuine interest on the side of researchers or the possibility that researchers are chasing other interests such as publication and citation counts. Thirdly, the narrative of digital technologies and the development they bring about, where the micro-level is concerned, is often based on 'areas of interventions' rather than on the 'approaches or models that cut across different policy areas' (James 2005:286). This creates a chasm between actual field experiences and the processes which are 'created and changed over time' (James 2005:286). While these interventions are valuable in their own rights, the failure to identify multiple possible pathways that emerge as individuals and communities engage with these technologies would fail to capture the parties' responses to the changes over time (Bar, Weber \& Pisani 2016; Boeri 2016; Sassen 2002).

Combined, these three views suggest an outcome- and impactorientated approach to digital technologies, and by extension, DL which include and benefit even the marginalised and impoverished sections of the society. The benefits arise through the fruitful interaction of the communities with the digital technologies, when the outcomes of appropriation (i.e. local improvements, adaptations, experimentation and innovations) are realised by the indigenous population (James 2005). Approriation is enhanced through competencies aimed at achieving better and more fulfilling lives (Cibangu et al. 2017:41). Certainly, the socio-economic pursuits associated with the progress in technology are neither new nor only applicable to digital technologies (Balasubramanian \& Mahajan 2001). For instance, Behrents' (2013) essay on Foucault and Technology discusses the societal and technological reconfigurations that were happening in France (and in other parts of the world) after the Second World War, with specific emphasis on the power dynamics. Behrent (2013) notes that Foucault's work, while largely philosophical, was set to conceptualise the complexity of the evolving relationship between 'objects and machines' within a system of power. In this conceptualisation, relations 'refer not to tools, machines, or the application of science to industrial production, but rather to methods and procedures for governing human beings' (Behrent 2013:56). That is, the focus on DL should also be concerned with the processes that create the required change in the relationship between the individuals and society on one side, and the digital technologies on the other side.

Digital literacy as a concept, has been viewed from a number of dimensions that do not seem to converge
(Brown, Czerniewicz \& Noakes 2016; Buckingham 2016). This ends up with overlapping and competing often divergent definitions (Helsper \& Eynon 2013). The definitions have moved from the classical view of literacy as 'being able to read and write', to other forms of literacies which seem to put the prevalent or dominant theme to the digital technology or the use of digital technology as adopted by the researcher. However, there seems to be concurrence: that the original focus of DL should be on the essential competencies of the present-day citizens' success in today's highly competitive and globalised market, which often require the performance of basic tasks using technology (Buckingham 2016). The competency-based view of literacy, traditionally approached literacy as being able to write, read and deal with information, also includes competencies in using the different digital technologies (Burton et al. 2015). Consequently, there is an emergent view that what is required is a holistic view of the multiple literacies or transliteracies (Burton et al. 2015; Stornaiuolo, Smith \& Phillips 2017) which are essential in a world dominated by dynamic perspectives on electronic media and technology (Buckingham 2016). These literacies enable individuals to appropriately respond, in socially recognised ways, to even future challenges through sharing and creating knowledge and eventually participating in the society (Merchant 2007). According to this emergent view, these multiple literacies cover both the mastery of information and communication technology (ICT) skills and generic and critical skills required to engage in social practices across boundaries of culture, institutions, countries and territories (Buckingham 2016; Burton et al. 2015; Lankshear \& Knobel 2007). The mastery is informed by changes in task requirements, technology and knowledge.

This view is in agreement with Labbo, Reinking and McKenna's (1998) typification of the DL process as encompassing aspects of lifelong learning, social context, the multiplicity of competencies and ability to assemble and produce knowledge while pursuing other goals. That is, the embeddedness of digital technologies requires a critical view of DL which, among others challenges and addresses the ideological concerns and the social and educational inequalities (Pangrazio 2016). The concerns and inequalities inhibit or promote individual practice and at the same time prioritise technical proficiency, thereby forming new norms and living without conscious awareness (Pangrazio 2016).

However, as much as the promises of digital technologies need to be acknowledged, it is important to note that they cannot completely displace older technologies. Rather, the digital technologies need to be appropriated alongside the existing technologies (Michailova 2011). If digital technologies do not replace the older technologies, then the intellectual traditions of the other disciplines and their view on literacy will still remain important (Goodfellow 2011; Hinrichsen \& Coombs 2013; Littlejohn, Beetham \& McGill 2012). In addition, the dynamism and inseparability of digital technologies and the society can favour, invite, shape or even constrain their use in society, as well as the conceptualisation of DL. That is, in addition to learning the operational and 
functional uses of technologies, users and user societies should be able to make informed decisions on the use of these technologies, based on their contexts and needs measured against outcomes and consequences of their use (Lankshear \& Knobel 2007; Moje 2009). Therefore, there is a need for clear distinctions between the digital technologies and the meaning derived from their uses, as well as the outcomes and consequences of the digital technologies from those of the technologies' uses (Lankshear \& Knobel 2007; Moje 2009). These distinctions require individuals to be empowered to take advantage of the positive outcomes while avoiding or mitigating the negative consequences (AmichaiHamburger et al. 2008; Maton 2008).

\section{Importance of context}

Following from the main approach in this article, the context is dynamic and inseparable from the issue of DL (Michailova 2011), and at the same time, it provides 'situational opportunities and constraints' that change 'occurrence and meaning' of behaviour and relationships (Johns 2006:386). That is, the DL should not be abstracted or idealised; rather, its meaning should be derived from its contexts. At the core of the contextualised definition is the compelling evidence that digital technologies and globalised networks not only promote and facilitate the movement of and interaction between people, languages and works of art, but that they also do so on a very large and fast scale. This is to the extent that people's daily lives and routines have become characterised by these movements and interactions (Stornaiuolo et al. 2017). However, the above context does not speak to all parts of the world or society. For instance, the majority of people in Africa are poor (Pangrazio 2016). Their context should be understood from their history, culture and power (Garrido et al. 2012). They have very limited control over changes in their lives (Garrido et al. 2012). Without contextualised definition, DL is seen as another way of propagating the already existing digital divide, where skills create new inequalities (Alam \& Imran 2015) arising from the 'variation in sophistication of use and user expertise' (Reynolds 2016:737). Indeed, the focus of the digital divide has shifted from access to digital technologies to the skills and capabilities required in appropriating these technologies (Alam \& Imran 2015; Baase 2012; Buckingham 2007).

Consequently, concerns have been raised about the broad definition and understanding of DL in relation to the context of use of these technologies. For instance, Pangrazio (2016) laments about a narrow focus on the 'digital', which lacks an understanding of what would make DL applicable in other contexts and media. Contextualisation is placing the DL within the cultural, historical, geographical, social and political realms of the individuals' concerns, and with the aim of achieving outcomes that may include life fulfilment or material satisfaction (Long et al. 2014). This process also involves bridging the gap between the providers and recipients of DL (Long et al. 2014), and addressing issues of redresses and resource redistribution to deal with historical inequities (Czerniewicz et al. 2006).
Regrettably, the available definitions seem to fall into two, almost mutually exclusive, positions. One focuses on the production of digital materials and the other on the consumption aspects. This subsequently limits the development of an inclusive framework that would meet the needs of the intended audience. Using the productionconsumption continuum, DL is then characterised on progressive levels of competence: with production being the topmost. According to this view, the rural and the marginalised are depicted as mere consumers, whose only role is limited to the use of both the technologies and their products. The challenge with this view is that while consumption is not bad, socio-economic development is dependent on how the use of these technologies and their products is beneficial to this group of people, as they move from simple consumption to actual production.

Still, these views of DL seem to have reduced DL to a competence or a skill of using a digital technology, discarding the original meaning of literacy, the ability to read and write (Buckingham 2007). This reduction in meaning is problematic. Defining DL without the context of use, reduces it to just mere competences, skills or abilities to use a digital technology whether for production of consumption. This reduction conceives of DL as possessing the basic skills required to perform given operations using digital technologies, while ignoring aspects of learning, 'problem solving, critical thinking, creativity, self-regulation' as well as the understanding of culture, a context of use of the digital technologies (Burton et al. 2015:152). By extension, a complete definition of DL should include the understanding of the contextual aspects - social, economic and cultural - of use of the digital technologies, as well as the critical aspects of learning - problem solving, critical thinking, creativity and self-regulation.

These contextual aspects are important as engagements in and with the digital technology simultaneously traverse space and time - whose understanding also requires reconfiguration. That is, the context-informed definition of DL is aware of the fact that the context of use of the digital technology requires mutually constitutive actions, social interactions, cultural and economic exchanges which interactively and dynamically shape, and are shaped by the digital technologies (Casey \& Bruce 2011). Therefore, 'digital literacy encompasses the purpose, setting and practices in which technology is used' (Casey \& Bruce 2011:77). That is, a variety of context of use should be considered when defining DL (Martin 2008).

\section{Digital technologies' interaction with society (and also society's interaction with digital technologies)}

Technologies and their use traverse both space and time; this brings along affordances that increase the dynamism in both the society and the digital technologies. As much as we 
appreciate these affordances, we also ought to recognise the constraints which these digital technologies put on the society (Zammuto et al. 2007). Any explanation of one will invariably involve the enactment of their entwined forms and functions in a cyclical relationship, that also involves their contexts of use - as they both dynamically inform each other. The time, space or context disparity means that despite the perceived pervasiveness of the digital technologies, their use may vary depending on, among others, the technologies' purposes and their interactions with society.

The difference between the social model of DL and the competency-based model of literacy has been documented in the literature (Buckingham 2007; Lankshear \& Knobel 2008). Buckingham (2007:48) notes that this issue is complex and needs to be fully addressed in terms of its aims as well as what DL actually entails, including 'systematic awareness of how digital media are constructed, and of the unique "rhetorics" of interactive communication'. To address this complex issue, there has been ongoing research and debates on digital technology, society and social change and their relationships, as well as the social change that includes critical theories, view of technology (Brey 2003; Sassen 2002). Brey (2003:54) argues that technology and society are co-constructed or 'deeply interwoven' and 'their meanings and functions and even (according to social constructivists) their contents are continually open to renegotiation by users and others'. There is therefore a need to reframe the digital technologies, to understand their impact on social development (Boeri 2016) while recognising the 'embeddedness and the variable outcomes of these technologies for different social orders' (Sassen 2002:365). The reframing should allow participants to 'recognize, interpret, and evaluate underlying ideologies' of linked information (Labbo et al. 1998:282) and could change our perception of DL.

As part of the reframing, the social constructivist view of DL drives the social determinism agenda, which seeks to place the 'human as an autonomous agent who holds a productive purpose driving technology use' (Reynolds 2016:737). Technology, and by extension DL, is therefore, shaped by individuals' participation in political, economic and sociocultural practices (Hinrichsen \& Coombs 2013). That is, technology and DL are never neutral. This is opposed to the technology determinism which views technology as valueneutral, having its own logic of making things happen independent of its 'sociocultural context', and that everyone should adopt (or adapt to its consequences) because of its universally positive impacts (Hinrichsen \& Coombs 2013). The technology deterministic view of DL is inadequate in that it would limit it to the skills required to use technology that currently exists, without recognising the ever-changing nature of technology and society, as it uses the technology (Reynolds 2016) and the more meaningful outcomes from the use of such technology (Watkins 2011). The social constructivist view therefore is seen as a way of having a definition of DL which does not go with the changes in technology, and one that holds that individuals have autonomy and agency (Reynolds 2016). However, the social constructivist view is not without limitations. Its most conspicuous limitation is its focus on actors 'directly relating or interacting with the technology-in-use'; this preoccupation therefore, leaves non-users out of the picture, even if they are affected by this technology (Müller \& Tworek 2016:106). Lamentably, these non-users are usually the impoverished and the manigalised who consititute the majority of the population.

With this in mind, DL and approaches to DL cannot be placed in universalised contexts. Consequently, any definition of literacy that is afforded by the digital technologies should attend to how digital technologies and society interact (Leonardi \& Barley 2010), while at the same time being aware of the fact that the literacies may be used differently in multiple contexts and even in different social structures (Tunçalp \& Tun 2016). Therefore, this calls for a definition or an understanding of DL as meaning-making practices that vary, depending on, among others, the settings, communities and identities in the digital environment (Chase \& Laufenberg 2011). To this end, O'Brien and Scharber (2008:66-67) view DL as 'socially situated practices supported by skills, strategies, and stances that enable the representation and understanding of ideas using a range of modalities enabled by digital tools'.

\section{The distinction between a tool and its use}

Combining context of use and of interaction between technology and society, there is a suggestion that an inclusive definition of DL should entail 'practices' which are socially recognised. That is, the technology, knowledge and skills triad, and the continuous changes in them, should be organised for ease of understanding of the people (Lankshear \& Knobel 2007). However, this fails to capture the intended outcomes and the consequences of the practice. Therefore, there is a need to distinguish between the tool and the meaning derived from using the tool. There is also a need to distinguish the outcomes and consequences of the tool from those of its use. According to Moje (2009), distinctions:

\footnotetext{
...between the tool (the media) and the norms or conventions that shape meaning making of the symbols offered via the tool (literate practices) are not only worth noting but are also worth distinguishing so that we can better understand the relative outcomes or consequences of each. (p. 349)
}

In the classical diffusion of innovation, the innovationdecision process is depicted as a cognitive process that individuals go through, from the time they become aware of an innovation to the time they make a final decision and a commitment to adopt or reject the innovation (Rogers 2003). However, in contemporary use of innovation, there is a further step of appropriation: ownership that could spur new uses (different from those originally intended), and especially 
new innovations that may arise in the course of use (Bar et al. 2016). They define appropriation as a:

...contest for control over a technological system's configuration, as users, designers, and manufacturers battle over who can use that technology, at what cost, under what conditions, for what purpose, and with what consequences. (Bar et al. 2016:618)

The conditions, for DL, include capabilities of the indigenous people to better their lives through the appropriation (Cibangu et al. 2017; James 2005). However, appropriation relies heavily on recognising how ideology and power are manifested in the innovation (Bhatt \& de Roock 2013), as well as imagining multiple distinctive future uses or purposes of the innovation that are different from the innovation's actual or originally intended use (Müller \& Tworek 2016).

At the end, the new determined use of the innovation could be different in not only having new tweaks and new service offerings, but also significantly new social, economic and practical opportunities. In extending this view, Bar et al. (2016) have argued that the success of the adoption of an innovations lies in understanding four main things (which they call assumptions):

${ }^{11}$ technology is not neutral and a technology's architecture forms relationships between stakeholders that have social, economic and political implications; ${ }^{22}$ adoption of technology is not for adoption sake, but it is aimed at making a difference in the adopter's life; ${ }^{33}$ past the adoption, the adaptations to the technology which occur take many forms; and ${ }^{44}$ cultural adaptations are 'uniquely creative' because, among other reasons, they challenge the original power structure that was embedded in the technology.

Following the appropriation route, then, defining DL should recognise the social, economic and political learning and the dialogues which take place to make meaning of the technology and to repurpose the technology to shape the outcomes and consequences of its use in a uniquely creative way. At the same time, this recognition extends to the outcomes and consequences not initially intended or imagined by the creators of the original technology.

\section{As a process of empowerment}

Digital literacy becomes a process of empowerment; it empowers an individual not only to use a tool but also to take advantage of the positive outcomes of the tool (or its use) while at the same time avoiding any negative consequences. Empowerment is aimed at linking an individual to the 'wider social and political environment' (Amichai-Hamburger et al. 2008:1776). Maton (2008) defines empowerment as:

\footnotetext{
...a group-based, participatory, developmental process through which marginalized or oppressed individuals and groups gain greater control over their lives and environments, acquire valued resources and basic rights, and achieve important life goals and reduced societal marginalization. (p. 5)
}

It is a process of removing unjust inequalities that inhibit the majority or big groups of people from exercising choices, choices that disrupt the status quo at various levels individual, group, organisational and community (AmichaiHamburger et al. 2008; Haugh \& Talwar 2016).

In most cases, the unjust inequalities are historical, often arising from either demographic characteristics or their physical or emotional difficulties (Riger 1993). Thus, a DL view of empowerment could be described as a means through which individuals acquire 'mastery and control over their lives, and a critical understanding of their environment' (Zimmerman et al. 1992:708). In order to influence their social, economic and political conditions (Gomez \& Baron-porras 2011) by acquiring or strengthening the necessary psychological resources in order to respond appropriately to their environment (Amichai-Hamburger et al. 2008). Thus, the empowerment is meant to capacitate someone to understand both the ideological dimensions and the cultural forms that encompass selective interests, and the relationships between what is happening in and with the individual and what is happening in the world (Mayo 1995).

The critical aspects of empowerment arising from these definitions can be classified into two broad categories: individual empowerment and community empowerment. Individual empowerment is seen as a participatory developmental process that is aimed at achieving goals often enhancing an individual's capacities to control and influence, among others, their economic, political, social and psychological capacities in order to increase self-sufficiency and decrease external dependence (Christens et al. 2016; Gomez \& Baron-porras 2011; Mayo 1995; Rappaport et al. 1995). As a parallel, community empowerment is also a participatory developmental process, but its goals differ in that they are about increasing community participation, reinforcing shared identification and increasing collaborative control by delegating or distributing power to the powerless (Riger 1993). By implication, even the empowerment process discussed here is dynamic. The activities within the process and indeed the individuals' goals, expectations and outcomes are in flux.

From the individual's perspective, goals attainment is the drive towards empowerment, and therefore enhancing the strengths and competencies is akin to acquiring the necessary resources towards the goals (Amichai-Hamburger et al. 2008). The process individuals go through in determining their goals is critical. In this process, individuals have to systematically go through and identify the causes of powerlessness and their interconnection to other individuals, groups and systemic factors that should be collectively addressed to facilitate empowerment (Bradbury \& Reason 2003). Zimmerman (1995) proposes a nomological framework of psychological empowerment, consisting of interpersonal, cognitive and behavioural components that could be applicable in this case. The interpersonal component is concerned with an individual's perceptions of influencing the sociopolitical domain; the cognitive component is concerned with the skills and competencies required to exert 
this influence; and the behavioural domain is concerned with the actions required to exert this influence. Viewed from an empowerment perspective, DL is a process where individual strengths and competencies are enhanced to enable the individual to be proactive to social policy, social changes, economic emancipation and political consciousness (Amichai-Hamburger et al. 2008; Gomez \& Baron-porras 2011; Zimmerman et al. 1992). Social policy and social change relate to the individual's standing in society, while economic emancipation deals with decisions on earning and spending an income (Haugh \& Talwar 2016). Political consciousness involves a critical reflection of the information available (Parrott \& Madoc-Jones 2008).

\section{Conclusion}

In this study, an argument has been presented for an elaborate and inclusive definition of DL. This elaborate and inclusive definition should be contextually placed within the socioeconomic context of use of the digital technologies, while weighing on the outcomes and consequences of these technologies and their use. In the argument, the contextual aspects inform the simultaneous engagement of the contexts with the digital technologies across time and space. This engagement continuously requires reconfiguration as new understanding of the interplay between the context, the digital technologies, the individual and the society, through the mutually constitutive actions, social interactions, cultural and economic exchanges (Casey \& Bruce 2011). In so doing, the view of DL captures the purpose of use of the digital technologies, the setting or the contexts as well as the practices that emanate in the use of digital technologies. Perhaps, the greatest challenge here would be the variety and uniqueness of context and social structures within these contexts, and the digital technologies as well as their use. To deal with this challenge, O'Brien and Scharber's (2008:66-67) view of DL as 'socially situated practices supported by skills, strategies, and stances that enable the representation and understanding of ideas using a range of modalities enabled by digital tools', is recommended. The range of modalities being enabled by these technologies, could cover the issues of appropriation of these technologies, as well as the social, economic and political changes on the one hand, and the technologies on the other hand.

Of course, this view requires us to reframe the understanding of DL based on the impact of the DL and the digital technologies on, among others, the social development, while at the same time recognising the inherent iterative interplay between literacy, technology and society. In focusing on the impacts, we place value on the way society and individuals within the society 'recognize, interpret, and evaluate underlying ideologies in various types of hypertextually linked information' (Labbo et al. 1998:282), which also changes the participants' view of DL. On empowerment, the focus is on the eventual outcome, or the intended outcome of the DL, and placing it within means through which individuals dynamically master and gain control over their lives. Individuals therefore need to not only have a critical understanding of the environment, but they should also be able to benefit from the environment. In this way, they will also be able to fulfil the self-interest of improving their lives.

\section{Acknowledgements Competing interests}

The author declares that he has no financial or personal relationships that may have inappropriately influenced him in writing this article.

\section{References}

Alam, K. \& Imran, S., 2015, 'The digital divide and social inclusion among refugee migrants: A case in regional Australia', Information Technology \& People 28, 344-365. https://doi.org/10.1108/ITP-04-2014-0083

Amichai-Hamburger, Y., McKenna, K.Y.A. \& Tal, S.-A.A., 2008, 'E-empowerment: Empowerment by the Internet', Computers in Human Behavior 24, 1776-1789. https://doi.org/10.1016/j.chb.2008.02.002

Avgerou, C., 2010, 'Discourses on ICT and development', Information Technologies and International Development 6, 1-18.

Baase, S., 2012, A gift of fire: Social, legal and ethical issue for computing technology, 4th edn., Pearson Education, Upper Saddle River, NJ.

Balasubramanian, S. \& Mahajan, V., 2001, 'The economic leverage of the virtual community', International Journal of Electronic Commerce 5, 103-138. https:// doi.org/10.1080/10864415.2001.1104421

Bar, F., Weber, M.S. \& Pisani, F., 2016, 'Mobile technology appropriation in a distant mirror: Baroquization, creolization, and cannibalism', New Media \& Society 18 , 617-636. https://doi.org/10.1177/1461444816629474

Behrent, M.C., 2013, 'Foucault and Technology', History and Technology 29, 54-104 https://doi.org/10.1080/07341512.2013.780351

Bhatt, I. \& De Roock, R., 2013, 'Capturing the sociomateriality of digital literacy events', Research and Learning Technology 21, 21281. https://doi.org/10.3402/ rlt.v21.21281

Boeri, N., 2016, 'Technology and society as embedded: An alternative framework for information and communication technology and development', Media, Culture \& Society 38, 107-118. https://doi.org/10.1177/0163443715607845

Bradbury, H. \& Reason, P., 2003, 'Action research', Qualitative Social Work 2, 155-175. https://doi.org/10.1177/1473325003002002003

Brey, P., 2003, 'Theorizing modernity and technology', in T.J. Misa, P. Brey \& A. Feenberg (eds.), Modernity and technology, pp. 33-71, MIT Press, Cambridge.

Brown, C., Czerniewicz, L. \& Noakes, T., 2016, 'Online content creation: Looking at students' social media practices through a connected learning lens', Learning, Media \& Technology 41, 140-159. https://doi.org/10.1080/17439884.2015. Media \&
1107097

Buckingham, D., 2007, 'Digital media literacies: Rethinking media education in the age of the Internet', Research in Comparative and International Education 2, 43-55. $\mathrm{https} / / /$ doi.org/10.2304/rcie.2007.2.1.43

Buckingham, D., 2016, 'Defining digital literacy', in B. Bachmair (ed.), Medienbildung in Neuen Kulturräumen. VS Verlag für Sozialwissenschaften, pp. 59-71, Wiesbaden. https://doi.org/10.1007/978-3-531-92133-4_4

Burton, L.J., Summers, J., Lawrence, J., Noble, K. \& Gibbings, P., 2015, 'Digital literacy in higher education: The rhetoric and the reality', in M.K. Harmes, H. Huijser \& P.A. Danaher (eds.), Myths in education, learning and teaching, pp. 151-172, Palgrave Macmillan, London. https://doi.org/10.1057/9781137476982_9

Casey, L. \& Bruce, B.C., 2011, 'The practice profile of inquiry: Connecting digital literacy and pedagogy', E-Learning Digital Media 8, 76-85. https://doi.org/10.2304/ elea.2011.8.1.7

Chase, Z. \& Laufenberg, D., 2011, 'Embracing the squishiness of digital literacy', Journal of Adolescent \& Adult Literacy 54, 535-537. https://doi.org/10.1598/ JAAL.54.7.7

Christens, B.D., Winn, L.T. \& Duke, A.M., 2016, 'Empowerment and critical consciousness: A conceptual cross-fertilization', Adolescent Research Review 1 15-27. https://doi.org/10.1007/s40894-015-0019-3

Cibangu, S.K., Hepworth, M. \& Champion, D., 2017, 'The impact of mobile phone uses in the developing world: Giving voice to the rural poor in the Congo', International Journal of Information Communication Technologies and Human Development 9 , 20-48. https://doi.org/10.4018/IJICTHD.2017040102

Czerniewicz, L., Ravjee, N. \& Mlitwa, N., 2006, ICTs and the South African higher education landscape, Council on Higher Education, South Africa, Pretoria.

El-Darwiche, B., Sharma, A., Singh, M. \& Samad, R.A., 2012, Digitization in emerging economies: Unleashing opportunities at the bottom of the pyramid, Strategy, Beirut.

Garrido, M., Sey, A., Hart, T. \& Santana, L., 2012, Literature review of how telecentres operate and have an impact on e-inclusion, European Commission, Seville. 
Gomez, R. \& Baron-porras, L.F., 2011, 'Does public access computing really contribute to community development? Lessons from libraries, telecentres and cybercafés in Colombia', The Electronic Journal of Information Systems in Developing Countries 49, 1-11. https://doi.org/10.1002/j.1681-4835.2011.tb00346.x

Goodfellow, R., 2011, 'Literacy, literacies and the digital in higher education', Teaching in Higher Education 16, 131-144. https://doi.org/10.1080/13562517.20 11.544125

Harris, R.W., 2016, 'How ICT4D research fails the poor', Information Technology for Development 22, 177-192. https://doi.org/10.1080/02681102.2015.1018115

Haugh, H.M. \& Talwar, A., 2016, 'Linking social entrepreneurship and social change: The mediating role of empowerment', Journal of Business Ethics 133, 643-658. https://doi.org/10.1007/s10551-014-2449-4

Helsper, E.J. \& Eynon, R., 2013, 'Distinct skill pathways to digital engagement', European Journal of Communication 28, 696-713. https://doi.org/10.1177/ 0267323113499113

Hinrichsen, J. \& Coombs, A., 2013, 'The five resources of critical digital literacy: A framework for curriculum integration', Research \& Learning Technology 21 21334. https://doi.org/10.3402/rlt.v21.21334

James, J., 2005, 'The global digital divide in the Internet: Developed countries constructs and third world realities', Journal of Information Science 31, 114-123. https://doi.org/10.1177/0165551505050788

Johns, G., 2006, 'The essential impact of context on organizational behavior', The Academy of Management Review 31, 386-408. https://doi.org/10.5465/ AMR.2006.20208687

Klecun, E., 2008, 'Bringing lost sheep into the fold: Questioning the discourse of the digital divide', Information Technology \& People 21, 267-282. https://doi.org/ 10.1108/09593840810896028

Labbo, L.D., Reinking, D. \& McKenna, M.C., 1998, 'Technology and literacy education in the next century: Exploring the connection between work and schooling', Peabody Journal of Education 73, 273-289. https://doi.org/10.1080/016195 6Xabody Journal

Lankshear, C. \& Knobel, M., 2007, 'Researching new literacies: Web 2.0 practices and insider perspectives', E-Learning \& Digital Media 4, 224-240. https://doi.org/ 10.2304/elea.2007.4.3.224

Lankshear, C. \& Knobel, M., 2008, 'Introduction. Digital literacies: Concepts, policies and practices', in Digital literacies: Concepts, policies and practices, pp. 1-16, Peter Lang Publishing, New York.

Leonardi, P.M. \& Barley, S.R., 2010, 'What's under construction here? Such social action, material, and power in constructivist studies of technology and organizing', Academy of Management Annals 4, 1-51. https://doi.org/10.1080/ 19416521003654160

Littlejohn, A., Beetham, H. \& McGill, L., 2012, 'Learning at the digital frontier: A review of digital literacies in theory and practice', Journal of Computer Assisted Learning 28, 547-556. https://doi.org/10.1111/j.1365-2729.2011.00474.x

Long, L.-A., Chamberlain, S. \& Gagnaire, K., 2014, 'The 80-20 Debate: Framework or fiction? How much development work is standardized across geographies, and how much is customized for local conditions', Innovations 9, 87-96. https://doi. org/10.1162/inov_a_00219

Martin, A., 2008, 'Digital literacy and the "digital society"', in C. Lankshear \& M. Knobe (eds.), Digital literaciesl - Concepts, policies and practices, pp. 151-176, Peter Lang Publishing, New York.

Maton, K.I., 2008, 'Empowering community settings: Agents of individual development, community betterment, and positive social change', American Journal of Community Psychology 41, 4-21. https://doi.org/10.1007/s10464 007-9148-6
Mayo, P., 1995, 'Critical literacy and emancipatory politics: The work of Paulo Freire', International Journal of Educational Development 15, 363-379. https://doi. org/10.1016/0738-0593(95)00021-T

Merchant, G., 2007, 'Writing the future in the digital age', Literacy 41, 118-128. https://doi.org/10.1111/j.1467-9345.2007.00469.x

Michailova, S., 2011, 'Contextualizing in international business research: Why do we need more of it and how can we be better at it?', Scandinavian Journal of Management 27, 129-139. https://doi.org/10.1016/j.scaman.2010.11.003

Moje, E.B., 2009, 'Standpoints: A call for new research on new and multi-literacies', Research in the Teaching of English 43, 348-362.

Müller, S.M. \& Tworek, H.J.S., 2016, 'Imagined use as a category of analysis: New approaches to the history of technology', History and Technology 32, 105-119. https://doi.org/10.1080/07341512.2016.1218957

O'Brien, D. \& Scharber, C., 2008, 'Digital literacies go to schools: Potholes and possibilities', Journal of Adolescent \& Adult Literacy 52, 66-68. https://doi. org/10.1598/JAAL.52.1.7

Pangrazio, L., 2016, 'Reconceptualising critical digital literacy', Discourse Studies in the Cultural Politics of Education 37, 163-174. https://doi.org/10.1080/01596306.20 14.942836

Parrott, L. \& Madoc-Jones, I., 2008, 'Reclaiming information and communication technologies for empowering social work practice', Journal of Social Work 8 181-197. https://doi.org/10.1177/1468017307084739

Rappaport, J., Altman, D., Arbor, A. \& Zimmerman, M.A., 1995, 'Psychological empowerment: Issues and illustrations', American Journal of Community Psychology 23, 581-599. https://doi.org/10.1007/BF02506983

Reynolds, R., 2016, 'Defining, designing for, and measuring "social constructivist digital literacy" development in learners: A proposed framework', Educational Technology Research and Development 64, 735-762. https://doi.org/10.1007/ s11423-015-9423-4

Riger, S., 1993, 'What's wrong with empowerment', American Journal of Community Psychology 21, 279-292. https://doi.org/10.1007/BF00941504

Rogers, D.E.M., 2003, Diffusion of innovations, 5th edn., Simon \& Schuster, New York.

Roztocki, N. \& Weistroffer, H.R., 2016,, 'Conceptualizing and research the adoption of ICT and the impact on socioeconomic development', Information Technology for Development 22, 541-549. https://doi.org/10.1080/02681102.2016.1196097

Sassen, S., 2002, 'Towards a sociology of information technology', Current Sociology 50, 365-388. https://doi.org/10.1177/0011392102050003005

Stornaiuolo, A., Smith, A. \& Phillips, N.C., 2017, 'Developing a transliteracies framework for a connected world', Journal of Literacy Research 49, 68-91. https:// doi.org/10.1177/1086296X16683419

Tunçalp, D. \& Tun, D., 2016, 'Questioning the ontology of sociomateriality: A critical realist perspective', Management Decision 54, 1073-1087. https://doi.org/ 10.1108/MD-07-2014-0476

Watkins, C.S., 2011, 'Digital divide: Navigating the digital edge', International Journal of Learning Media 3, 1-12. https://doi.org/10.1162/ijlm_a_00072

Zammuto, R.F., Griffith, T.L., Majchrzak, A., Dougherty, D.J. \& Faraj, S., 2007, 'Information technology and the changing fabric of organization', Organization Science 18, 749-762. https://doi.org/10.1287/orsc.1070.0307

Zimmerman, M.A., 1995, 'Psychological empowerment: Issues and illustrations', American Journal of Community Psychology 23, 581-599. https://doi.org/10.1007/BF02506983

Zimmerman, M.A., Israel, B.A., Schulz, A. \& Checkoway, B., 1992, 'Further explorations in empowerment theory: An empirical analysis of psychological empowerment', American Journal of Community Psychology 20, 707-727. https://doi.org/10.1007/ BF00942234 